\title{
The Way of Realizing Innovative and International Talents Training in Universities and Colleges of Jilin Province
}

\author{
Yang $\mathrm{Li}^{1}$, Zhichao $\mathrm{Xu}^{1}$, Ren Song ${ }^{1}$, Biming Liang ${ }^{1, *}$ \\ ${ }^{1}$ Jilin University of Finance and Economics, Changchun, Jilin Province, China \\ *Corresponding author
}

Keywords: Jilin Province, Innovation, Internationalization, Talents Training, Way Of Realizing.

\begin{abstract}
Under the background of knowledge economy, the competition of talents is becoming increasingly fierce. At present, higher education is at a critical stage of development. It has become a unanimous choice for universities and colleges all over the world to reform their talents training modes, and cultivate talents with innovative and international capacities. This paper analyzes the current situation and problems in the talents training mode in universities and colleges of Jilin, and focuses on how to realize innovative and international talents training in universities and colleges of Jilin province.
\end{abstract}

\section{Introduction}

The competitions in countries are attributed to that of talent. The core of economic development and social progress is the cultivation of innovative and international talents. In the era of economic globalization and knowledge information, China's economy is in a transition stage, facing the historical task of integrating into the international community. It is an inevitable choice for higher education institutions to cultivate high level talents with innovative abilities, team spirit, international skills, intercultural communication competence and the ability of understanding multiculture.

Outline of National Medium-and-Long-Term Program for Education Reform and Development (2010-2020) points out, "improving quality is the core task of higher education, and the basic requirement of constructing a powerful country in higher education." Universities in Jilin respond positively to these requirements, and strive to explore the path of realizing innovative and international talent training, trying to improve the quality of talents training and cultivate far-sighted personage for our country.

\section{Present Situation on University Talents Training of Jilin Province}

At present, there are 58 general institutes of higher education in Jilin, including 3 "211 Project" universities. In 2015, student's enrollment in universities and colleges of Jilin province reached 632,723; the number of full-time teachers was 39152. The student teacher ratio was 16.16:1. Compared with data over the past years, it can be found that the numbers of college students and full-time teachers are increasing, which pose a challenge to the implementation of talents training plan. The present situation on talent training in universities and colleges of Jilin are shown as following. 


\begin{tabular}{ll}
\hline training conception & $\begin{array}{l}\text { Schools pay attention to the training of applied and technical } \\
\text { talents, but ignore the cultivation of students' } \\
\text { internationalization competence. }\end{array}$ \\
\hline $\begin{array}{l}\text { discipline and } \\
\text { program system }\end{array}$ & $\begin{array}{l}\text { Schools adopt double degree system. Students can choose to } \\
\text { change their majors, but it is quite difficult. }\end{array}$ \\
\hline curriculum setting & $\begin{array}{l}\text { General education courses, second classrooms and innovative } \\
\text { courses are introduced. Some universities also organize seminars } \\
\text { for freshmen. }\end{array}$ \\
\hline teaching condition & $\begin{array}{l}\text { Books, equipment and other materials can basically meet current } \\
\text { needs. }\end{array}$ \\
\hline $\begin{array}{l}\text { international } \\
\text { exchange and } \\
\text { cooperation }\end{array}$ & $\begin{array}{l}\text { International cooperation and exchange offices are established to } \\
\text { contact with overseas schools. Several colleges and universities } \\
\text { have long-term overseas exchange projects for teachers and } \\
\text { students. }\end{array}$ \\
\hline $\begin{array}{l}\text { Sino-foreign } \\
\text { cooperative } \\
\text { education }\end{array}$ & $\begin{array}{l}\text { 25 universities have carried out Sino-foreign cooperation; most } \\
\text { cooperative majors are in low running costs and have good } \\
\text { market efficiency. }\end{array}$ \\
\hline $\begin{array}{l}\text { entrepreneurial } \\
\text { practice }\end{array}$ & $\begin{array}{l}\text { Schools have established entrepreneurial parks, organizing } \\
\text { entrepreneurial activities and competition. }\end{array}$ \\
\hline
\end{tabular}

Practice survey results show that, the mode is helpful to cultivate integrated talents. It can improve the knowledge structure of students, and meet current market demands. Secondly, various universities have established friendly relations with overseas schools; some schools even organize the exchange of students and teachers regularly. It is good to broaden their horizons, and lays a solid foundation for cultivating their international abilities. In addition, the practice of entrepreneurship and second classroom activities are also conducive to broaden students' breadth of knowledge, and can cultivate their practice and innovation abilities. As a whole, universities in Jilin have set up the mode of cultivating innovative and international talents, but there are still some problems that need to be solved.

\section{Main Problems in Talent Training Mode of Colleges and Universities in Jilin}

Simple target of talent training. Higher education in our country is carried out according to a highly centralized school running system. The state always formulates and implements unified training targets, subjects, the model of curriculum and teaching methods. The long-term implementation of such a school system will inevitably lead to the simple target of talent-cultivating. Although we have reformed, it is difficult to solve the problem ultimately in short term. Graduates of the same major have similar skills and knowledge, and do not have unique competitiveness. At the same time, talents with the spirit of innovation and other types of skills are in short supply. Enterprises cannot recruit suitable graduates, while graduates cannot find appropriate jobs. The unified, simple training target cannot adapt to the needs of social development. [1]

Limited high-quality teachers. According to the data of colleges and universities, now in institutes of higher education in Jilin province, there are 10 academicians, 36 Chang Jiang Scholars and 2 national outstanding young scholars. These numbers account for $0.76 \%, 2 \%$ and $1 \%$ of the whole country, and directly affect the capacity of scientific research and the level of discipline construction of colleges and universities in our province, as well as their influences and competitiveness comparing with schools in other areas.

Brain drain phenomena have been obvious in Jilin province for a long time. Jilin is lack of geographical advantages; its economic development is relatively backward. Attracting and retaining talents is an arduous task. With the continuous expansion of enrollment, the speed of teachers training 
cannot consistent with the growth of students, which brings difficulties in drawing advanced experience from other schools, and cultivating international and innovative talents.

In addition, fewer teachers have overseas study experience, and can only provide limited help on students' international competence cultivation. Some teachers are lack of teaching theories; their lectures are not vivid enough to attract students' attention. The content of their courses is relatively empty and monotonous, which further limits the implementation of talent training plan.

Unreasonable teaching management system. Through practical investigation, it is found that although selective courses are set up, college students cannot choose courses independently. They have to comply with provisions in the school plan. They cannot choose courses of other majors in accordance with their personal interests and hobbies, which further limits students' personality and future development. The credit system is not really implemented; students' individual training plans are also affected.

At present, although colleges and universities in Jilin province have introduced the major adjustment mechanism, most of them only allow top grade students who never fail the exam to change major. The system tends to hinder students with real needs, and reduce their study enthusiasm. Some universities have recognized the defects and limitations of this system, but the pace of reform is still slow, and only a small number of students have the right of changing their majors.

Lacking of teaching resources. In order to cultivate students' ability of internalization, the majority of colleges and universities in Jilin Province introduce sino-foreign cooperative projects. But they seem to ignore the actual situation of school, causing the lack of teachers and corresponding resources, which affects the teaching quality. On the other hand, most overseas schools in these projects are unknown; high quality teaching resources are extremely scarce.

\section{The Way of Realizing Innovative and International Talents Training in Colleges and Universities of Jilin}

Establishing training objectives. Colleges and universities in Jilin should improve their understanding on concepts and functions of talent training. The idea of talent cultivation has important guiding and regulating functions for the construction of talent training mode. Only with scientific concepts on talent training, can we design and perfect other elements of the system, such as setting reasonable and specific training objectives, major setup and curriculum modes, and teaching system. Therefore, it is necessary to fully understand the functions of talent cultivation concept, in order to construct and perfect the mode of individualized talents training.

Standardize internal management. The effect of talent training mode is closely related to internal teaching quality management and supervision. Colleges and universities in Jilin should combine the basic situation of the province with specific circumstances on faculty and student resources of the school, and establish a relatively perfect internal management system to implement supervision on teaching objectives, teaching process, evaluation and information feedback of each class, in order to provide support for the implementation of talents training plan.

In foreign affairs, personnel with foreign language foundation, intercultural communicative ability and understanding of international exchange project should be selected to ensure the smooth implementation of the project. For teacher's management, regular training and learning activities should be organized; teachers' teaching attitudes, professional levels and teaching achievements should be regularly supervised.

Improving school running structure. On the existing foundation of Chinese and foreign higher education institutions cooperation, colleges and universities in Jilin should seek to cooperate with better overseas schools. For instance, on the basis of precise localization, Jilin University and Northeast Normal University can seek joint running school projects for master and doctoral students, and introduce high level teacher on the basis of their own professional advantages. These methods will help to cultivate innovative and international talents.

Compared with other parts of China, the mode of cooperation between Chinese and foreign universities in Jilin province develops slowly and is at a low level. According to the economic development situation and market demands of Jilin province, education departments should 
investigate and study the present situation of foreign cooperation and exchanges in colleges and universities comprehensively; a special fund should be established by the government and proper schools or institutions to improve the current educational structure. [2]

Constructing curriculum system. The most important thing in the adjustment of curriculum structure is to improve the proportion of general courses. At present, most general courses in universities and colleges of our province are online courses; while in the classroom, these general courses are represented by politics, PE, English and so on. It is difficult to achieve the basic purpose of general education. The proportion of elective courses about natural science, social science and humanity should be increased. Students can take part in some specified elective courses, and select other courses according to their personal hobbies.

Secondly, school authorities need to reduce compulsory courses, and increase the proportion of elective courses. Students need to select courses independently to realize personality cultivation, which can help students to enjoy autonomy and subjectivity, and become integrated talents. [3]

Perfecting teaching quality evaluation. Teaching quality evaluation plays an important role in the whole teaching process; appropriate teaching quality evaluation methods can guide students' personality development.

First, schools need to set up the main purpose of the evaluation as feedback, correction and control the teaching quality; training and teaching quality improving should also be included in the system. Second, in the evaluation scope, schools should not only pay attention to the implementation of evaluation results, but also attach importance to the process evaluation, including students' performance in classroom, especially in seminar and discussion classes, individual reading and research achievements, communication with mentor, cooperative learning achievements, test scores and some non intelligence elements. Third, evaluation should not only rely on test scores. Creative thinking and practical abilities of students should also be taken into account. When design tests, teachers should fully understand the role of examination papers, and provide application and innovation thinking space for students. Fourth, in the evaluation method, schools need to change the single method of exam, and adopt a more diversified method to evaluate the advantages and disadvantages of students. School authorities need to reduce the proportion of examination results in teaching evaluation, trying to explore a more diversified and flexible evaluation method. Classroom discussion, independent research, writing research papers, reviews, designing experiment, interview and other methods can all be used to assess students' scientific, cultural and psychological qualities. [4]

Paying attention to the quality development of students. The university is the temple of knowledge, as well as the temple of cultivating students' personality and developing their qualities. Compared with traditional education, modern education pays more attention to the cultivation of students' creative ability. Today, quality education and individualized development projects have been truly launched. The tasks of higher education contain not only "imparting knowledge", but also "educating people". Besides certificate and diploma, teachers should also teach students to be honest, brave, strong and responsible. Relying on the mode of hidden curriculum, teachers need to encourage students to participate in extracurricular activities, and pay attention to mutual communications. In this way, dormitories, classrooms and other places will become communication and learning communities for students; these valuable experiences will become their spiritual wealth.

\section{Acknowledgements}

Fund Project: This paper is one of the outcomes of the research, Localization Mode of Cultivating Innovative and International Talents in Colleges and Universities in Jilin Province, which is supported by Foundation for Educational Programming Projects of Jilin Province (Contract No: GH150278); the research Course Construction for MPAcc Professional Degree Graduates in Local Universities of Finance and Economics in Jilin Province, which is supported by Foundation for Teaching Reform Projects in Jilin Province in 2016, and the research Construction of Comprehensive and Interdisciplinary Simulated Practice Training Platform in Universities of Finance, which is supported by Foundation for Scientific and Technological Projects of The Thirteenth Five-Year Plan 
of Jilin Provincial Department of Education (Contract No: JJKH20170122KJ). This paper is funded by the research, Localization Mode of Cultivating Innovative and International Talents in Colleges and Universities in Jilin Province, which is supported by Foundation for Educational Programming Projects of Jilin Province (Contract No: GH150278).

\section{References}

[1] H.X. Yang, Reforming the talent training mode and improving the quality of personnel training: a survey report on the pilot reform of national education system, J. China Higher Education Research. 10 (2014) 44-51.

[2]X. Xiang, H.R. Hou, N. Tang, Cooperative education in universities and colleges in Jilin Province: current situation, problems and countermeasures, J. Modern Education Science.02 (2017) 19-27.

[3] S.L. Huang, Reflect on university personnel training modes, J. Jiangsu Higher Education. 06 (2012) 98-99.

[4] W. Zhang, Y.L. Du, W. Ding, Realistic reflection and contemporary innovation of talent training modes, J. Educational Research. 01 (2015) 28-34. 